\title{
Peran Dukungan Sosial di Tempat Kerja Terhadap Keterikatan Kerja Karyawan
}

\author{
Ferry Iswanto, Ike Agustina \\ ferry.iswanto44@gmail.com
}

Program Studi Psikologi, Universitas Islam Indonesia, Yogyakarta, Indonesia

\begin{abstract}
Penelitian ini bertujuan untuk mengetahui hubungan antara dukungan sosial di tempat kerja dan keterikatan kerja. Hipotesis yang diajukan dalam penelitian ini adalah terdapat hubungan positif antara dukungan sosial di tempat kerja dan keterikatan kerja. Subjek dalam penelitian ini melibatkan karyawan tetap yang telah bekerja minimal satu tahun di perusahaan BUMN dan BUMD, yang berjumlah 164 subjek terdiri dari 95 orang laki-laki dan 69 orang perempuan. Alat ukur yang digunakan adalah modifikasi Utretch Work Engagement Scale yang dikembangkan oleh Schaufeli dan Bakker (2003). Sementara itu, untuk skala keterikatan kerja dan skala dukungan sosial di tempat kerja dikembangkan sendiri oleh peneliti. Hasil analisis data menggunakan product moment dari Pearson dengan bantuan SPSS 18.0 for Windows. Hasil yang diperoleh menunjukkan bahwa ada hubungan yang signifikan antara dukungan sosial di tempat kerja dan keterikatan kerja dengan koefisien $r$ sebesar 0.498 dan $\mathrm{p}=0.000(\mathrm{p}<0.01)$.
\end{abstract}

Kata kunci: dukungan sosial; keterikatan kerja

\section{Pendahuluan}

Organisasi merupakan sarana bagi individu untuk mengaktualisasikan diri. Bergabung dengan organisasi dapat memberikan dampak yang baik bagi individu maupun organisasi itu sendiri. Memiliki tujuan yang sama antara organisasi dengan individu akan menciptakan hubungan yang saling menguntungkan. Organisasi akan mendapatkan keuntungan berupa kemajuan organisasi, sedangkan individu akan mendapatkan keuntungan berupa pengembangan diri hingga reward.

Individu yang serius menggeluti pekerjaannya pasti mengerti seluk-beluk tentang pekerjaannya. Hal ini dapat disebabkan oleh keterikatan individu yang intens serta memahami benar pekerjaan itu sendiri. Dengan begitu, individu tidak perlu mendapat pengarahan lagi dari atasan untuk pekerjaan yang harus dilakukan. Individu yang memiliki keterikatan kerja yang baik juga lebih terbuka pada peluang dan dapat membangun relasi dengan baik (Gorgievski \& Bakker, 2010). Dengan memiliki sikap dan tingkat aktivitas yang positif, individu akan membuat umpan balik positif sendiri, dalam hal apresiasi, pengakuan, serta keberhasilan. Walaupun individu merasa lelah setelah seharian bekerja keras, individu menggambarkan kelelahan itu sebagai suatu keadaan yang menyenangkan karena terkait dengan prestasi positif (Bakker, Albrecht, \& Leiter, 2011).

Organisasi mengharapkan anggota organisasi harus proaktif, menunjukkan inisiatif, self-directed, dan bertanggung jawab atas perkembangan dan performa individu itu sendiri (Bakker dkk., 2008). Dengan kata lain, organisasi membutuhkan anggota organisasi yang berenergi, berdedikasi, dan berkonsentrasi penuh terhadap pekerjaan mereka, atau memiliki ikatan terhadap pekerjaannya. Organisasi akan merasa sangat senang memiliki anggota dengan keterikatan kerja yang baik. Organisasi tidak perlu bekerja keras 
memberi perintah kepada anggotanya untuk bekerja sesuai dengan perintah yang diberikan. Bahkan, anggota organisasi akan meminta pekerjaan lagi apabila telah menyelesaikan pekerjaannya. Organisasi membutuhkan anggota dengan keterikatan kerja yang baik. Dengan semakin banyaknya anggota yang memiliki keterikatan kerja yang baik, maka organisasi akan bergerak semakin maju dan berkembang. Keterikatan kerja memiliki manfaat bagi organisasi dan anggota organisasi yang berhubungan dengan beberapa hasil kerja yang baik, di antaranya kinerja tugas, perilaku anggota organisasi, dan kepuasan pelanggan (Brummelhuis \& Bakker, 2012).

Konsep mengenai keterikatan kerja pertama kali dicetuskan oleh William Kahn pada tahun 1990. Kahn (1990) menggambarkan keterikatan kerja sebagai "yang memanfaatkan anggota organisasi". Individu yang sepenuhnya secara fisik, kognitif, dan emosi terhubung dengan pekerjaannya. Hal ini dapat dihubungkan dengan konsep mengenai flow yang dikembangkan oleh Cziksentmihalyi (1990). Flow mengarah kepada integrasi karena pikiran, niat, perasaan, dan indra terfokus pada tujuan yang sama. Setelah mengalami flow, individu merasa lebih terarah dari sebelumnya, tidak hanya secara internal tetapi juga terhadap orang lain dan dunia pada umumnya.

Schaufeli dan Bakker (2004) sebagai peneliti yang meneruskan perkembangan teori mengenai keterikatan kerja mengungkapkan bahwa keterikatan kerja adalah hubungan terhadap pekerjaan yang aktif dan positif yang ditandai dengan semangat, dedikasi, dan penyerapan. Semangat mengacu pada tingkat energi yang tinggi dan resiliensi mental pada saat bekerja, sedangkan dedikasi mengacu pada ketahanan dalam bekerja meliputi sikap antusias dan menyukai tantangan. Kemudian, penyerapan ditandai dengan sepenuhnya berkonsentrasi, bangga, dan bahagia dalam bekerja, seperti waktu yang berlalu dengan cepat.

Bakker (2011) mengatakan faktor pendorong dari keterikatan kerja adalah sumber pekerjaan dan pribadi individu itu sendiri. Faktor dalam diri individu berperan untuk meningkatkan keterikatan kerja contohnya adalah pengetahuan. Memiliki pengetahuan terhadap pekerjaan yang digeluti membuat individu paham akan apa yang harus dikerjakan dan bagaimana mengerjakannya. Memahami pekerjaan dari hulu hingga ke hilir menandakan bahwa individu benar-benar terlibat dengan pekerjaannya. Sedangkan untuk faktor sumber pekerjaan, hal ini berhubungan dengan lingkungan pekerjaan dan pekerjaan itu sendiri, mulai dari organisasi hingga rekan kerja. Situasi dan kondisi organisasi pun dapat mempengaruhi keterikatan kerja individu.

Keterikatan kerja yang kurang baik akan membuat anggota organisasi malas dan tidak sepenuh hati bekerja. Pekerjaan akan diselesaikan dengan asal-asalan dengan berlandaskan yang penting cepat selesai. Anggota organisasi juga tidak dapat memahami bagaimana seharusnya pekerjaan itu dilakukan dan dampaknya bagi organisasi. Studi terkini menunjukkan keterikatan kerja akan mengalami fluktuasi dari hari ke hari. Hal ini akan membuat keterikatan kerja anggota organisasi menjadi naik turun setiap harinya (Schaufeli, 2012). Survei yang dilakukan oleh Fermin (2014) menyatakan bahwa terdapat 13 dampak dari keterikatan kerja yang kurang baik, di antaranya adalah karyawan yang tidak memiliki keterikatan kerja berpotensi meng- 
habiskan lebih dari 500 juta US Dollar dalam setahun di Amerika.

Sinokki (2011) mengatakan bahwa dukungan sosial dibangun dengan multidimensi atau jenis dukungan yang berbeda. Dimensi penting dari dukungan sosial adalah emosional, penilaian, informasi, dan dukungan instrumental. Dukungan emosional (afeksi) meliputi perasaan peduli, empati, kasih sayang, dan kepercayaan. Dukungan emosional adalah kategori yang paling penting di mana persepsi dukungan disampaikan. Dukungan penilaian meliputi komunikasi informasi yang relevan dengan evaluasi diri dan disebut sebagai dukungan penguatan yang diberikan oleh orang lain. Dukungan informasi merupakan informasi yang diberikan ke orang lain selama masa bekerja. Sementara itu, dukungan instrumental (bantuan) meliputi penyediaan barang berwujud, jasa, atau bantuan nyata.

Dukungan sosial di organisasi memiliki peran penting untuk membangun lingkungan sosial yang sehat dan bersahabat. Lingkungan sosial yang sehat dan bersahabat juga akan membentuk komunikasi interpersonal yang baik. Hal ini akan menjadi dukungan bagi anggota organisasi ketika bekerja. Dukungan sosial membuat anggota organisasi semangat untuk melakukan pekerjaan walaupun dirasa begitu berat. Semangat dan dukungan yang diberikan pada anggota organisasi akan mampu mengubah perasaan yang semula jenuh dalam bekerja menjadi ceria dan bersemangat kembali.

Berdasarkan penjabaran di atas, peneliti melihat adanya kaitan antara dukungan sosial di tempat kerja dan keterikatan kerja. Oleh karena itu, peneliti tertarik untuk melihat apakah ada hubungan antara dukungan sosial di tempat kerja dan keterikatan kerja.
Berdasarkan uraian di atas, maka peneliti mengajukan hipotesis yang akan diuji kebenarannya, yaitu "terdapat hubungan positif antara dukungan sosial di tempat kerja dan keterikatan kerja". Semakin tinggi tingkat dukungan sosial di tempat kerja, maka akan semakin tinggi pula tingkat keterikatan kerja. Demikian pula sebaliknya, semakin rendah tingkat dukungan sosial di tempat kerja, maka semakin rendah pula tingkat keterikatan kerja.

\section{Metode}

Desain dalam penelitian ini menggunakan pendekatan kuantitatif korelasional, yaitu penelitian kuantitatif yang mencari hubungan antara dua variabel atau lebih. Subjek penelitian yang akan diberikan pengukuran adalah karyawan BUMN maupun BUMD yang berjenis kelamin laki-laki dan perempuan. Karyawan yang dimaksud adalah karyawan tetap dan telah bergabung minimal satu tahun. Dasar dari penetepan karakteristik subjek telah bergabung minimal satu tahun adalah bahwa dengan waktu satu tahun, karyawan telah beradaptasi dengan baik di lingkungan sosialnya dan telah mengenal baik rekan-rekan kerjanya.

Metode pengumpulan data yang dilakukan dalam penelitian ini adalah dengan metode skala. Skala merupakan kumpulan pernyataan-pernyataan yang harus diisi oleh subjek penelitian. Penggunaan skala dalam penelitian ini didasarkan pada suatu asumsi bahwa subjek merupakan orang yang paling tahu mengenai dirinya sendiri, sehingga apa yang dinyatakan oleh subjek adalah sesuatu yang benar-benar menggambarkan tentang kondisi dan sikap dirinya (Azwar, 2012).

Skala keterikatan kerja dalam penelitian ini adalah adaptasi dari alat ukur Utrecht Work engagement Scale yang dikembangkan oleh 
Schaufeli dan Bakker (2003). Skala ini terdiri dari 17 aitem yang terdiri dari 6 aitem vigor (semangat), 5 aitem dedication (dedikasi), dan 6 aitem absorption (penyerapan). Tidak ada aitem unfavorable dalam skala ini. Skala Dukungan Sosial dalam penelitian ini dikonstruksi sendiri oleh peneliti. Skala ini terdiri dari 44 aitem yang terdiri dari 11 aitem dukungan emosional, 11 aitem dukungan instrumental, 11 aitem dukungan informasi dan 11 aitem dukungan penilaian serta tidak ada aitem unfavorable dalam skala ini.

\section{Hasil}

\section{Uji asumsi}

Uji asumsi merupakan proses awal sebelum dilakukan uji hipotesis, yang meliputi uji normalitas dan uji linieritas terhadap sebaran data penelitian yang ada. Pengujian asumsi dilakukan dengan menggunakan program statistika yaitu SPSS for Windows versi 18.

\section{Uji normalitas}

Uji normalitas dilakukan untuk mengetahui apakah sebaran data penelitian terdistribusi secara normal atau tidak pada populasi. Uji normalitas dilakukan dengan menggunakan One-Sample KolmogorovSmirnof Test. Uji normalitas digunakan untuk menguji apakah sebaran data variabel dalam peelitian ini terdistribusi secara normal atau tidak. Kaidah yang digunakan adalah apabila p>0.05 maka sebaran data normal, tetapi jika nilai $\mathrm{p}<0.05$ maka sebaran tidak normal.

Tabel 1

Hasil uji normalitas

\begin{tabular}{lccc}
\hline \multicolumn{1}{c}{ Variabel } & KS-Z & (p) & Ket. \\
\hline $\begin{array}{l}\text { Keterikatan } \\
\text { kerja }\end{array}$ & 1.092 & 0.184 & Normal \\
$\begin{array}{l}\text { Dukungan } \\
\text { sosial }\end{array}$ & 1.268 & 0.080 & Normal \\
\hline
\end{tabular}

Hasil uji asumsi pada variabel keterikatan kerja dan dukungan sosial menunjukkan sebaran data yang yang normal. Variabel keterikatan kerja dengan koefisien KS-Z 1.092 dan $\mathrm{p}=0,184$ ( $\mathrm{p}>0.05$ ), sedangkan untuk variabel dukungan sosial menunjukkan koefisien KS-Z 1.268 dan p=0.080 (p>0.05).

\section{Uji linieritas}

Uji asumsi linieritas merupakan pengujian garis regresi antara kedua variabel dalam penelitian, yaitu variabel dependen dan variabel independen. Uji linieritas bertujuan untuk melihat adanya hubungan yang linier antara kedua variabel dalam penelitian. Hubungan antara keduanya dikatakan linier apabila $\mathrm{p}<0.05$. Apabila $\mathrm{p}>0.05$, maka hubungannya dapat dikatakan tidak linier.

Tabel 2

Hasil uji linieritas

\begin{tabular}{lccc}
\hline Variabel & $(\mathbf{F})$ & $(\mathbf{p})$ & Ket \\
\hline $\begin{array}{l}\text { Dukungan } \\
\text { sosial dan } \\
\text { keterikatan } \\
\text { kerja }\end{array}$ & 67.174 & 0.000 & Linier \\
\hline
\end{tabular}

Hasil uji linieritas menunjukkan bahwa hubungan antara dukungan sosial di tempat kerja dan keterikatan kerja tidak mengikuti garis linier. Hal tersebut dapat dilihat pada tabel di atas dengan koefisien linieritas $\mathrm{F}=67.174$ dan $\mathrm{p}=0.000(\mathrm{p}<0.05)$.

\section{Uji hipotesis}

Setelah melakukan uji asumsi, langkah selanjutnya adalah melakukan uji hipotesis. Uji hipotesis dilakukan untuk melihat apakah ada hubungan antara dukungan sosial di tempat kerja dan keterikatan kerja. Uji hipotesis dalam penelitian ini menggunakan uji korelasi product moment Pearson.

$$
\text { Hasil uji hipotesis (Tabel 3) }
$$
menunjukkan data koefisien korelasi $\mathrm{R}=0.498$ dengan $p=0.00 \quad(p<0.05)$. Hal tersebut 
menunjukkan bahwa ada hubungan positif dan sangat signifikan antara dukungan sosial di tempat kerja dan keterikatan kerja. Artinya, semakin tinggi dukungan sosial di tempat kerja, maka semakin tinggi pula keterikatan kerja. Begitu pula sebaliknya, semakin rendah dukungan sosial di tempat kerja, maka semakin rendah pula keterikatan kerja. Oleh karena itu, hipotesis pada penelitian ini yaitu hubungan antara dukungan sosial di tempat kerja dan keterikatan kerja diterima. Adapun koefisien determinasi $\left(\mathrm{r}^{2}\right)$ variabel dukungan sosial di tempat kerja sebesar 0.248. Hal ini menunjukkan bahwa dukungan sosial di tempat kerja memberikan sumbangan sebesar $24.8 \%$ terhadap keterikatan kerja.

Tabel 3

Uji hipotesis

\begin{tabular}{cccc}
\hline $\mathbf{R}$ & $\mathbf{R}^{\mathbf{2}}$ & $\mathbf{( p )}$ & $\mathbf{K e t .}$ \\
\hline 0.498 & 0.248 & 0.000 & Ada korelasi \\
\hline
\end{tabular}

Uji beda

Uji beda merupakan prosedur yang digunakan untuk membandingkan rata-rata dua variabel dalam satu grup. Hal ini berarti analisis tersebut berguna untuk melakukan pengujian terhadap dua sampel yang berhubungan atau dua sampel berpasangan. Uji beda bertujuan untuk mengetahui ada tidaknya perbedaan tingkat keterikatan kerja berdasarkan perusahaan yang menjadi tempat penelitian. Keterikatan kerja dapat dikatakan memiliki perbedaan apabila nilai signifikansi yaitu $\mathrm{p}<0.05$. Hasil uji beda dapat dilihat pada tabel berikut.

Tabel 4

Uji beda berdasarkan perusahaan

\begin{tabular}{cccc}
\hline Variabel & Perusahaan & F & (p) \\
\hline $\begin{array}{c}\text { Keterikatan } \\
\text { kerja }\end{array}$ & $\begin{array}{c}\text { Perbankan, } \\
\text { PDAM }\end{array}$ & 1.551 & 0.965 \\
\hline
\end{tabular}

Berdasarkan tabel di atas, hasil uji beda pada keterikatan kerja berdasarkan perusahaan, diperoleh nilai $\mathrm{F}=1.551$ dengan $\mathrm{p}=0.965(\mathrm{p}<0.05)$. Hal ini dapat dikatakan bahwa tidak terdapat perbedaan yang signifikan pada keterikatan kerja antara perusahaan perbankan dan PDAM.

\section{Diskusi}

Penelitian ini dilakukan bertujuan untuk menguji hipotesis hubungan antara dukungan sosial di tempat kerja dan keterikatan kerja. Berdasarkan analisis statistik yang telah dilakukan peneliti dengan menggunakan teknik korelasi product moment dari Pearson menunjukkan bahwa terdapat hubungan positif yang sangat signifikan antara dukungan sosial di tempat kerja dan keterikatan kerja dengan nilai $\mathrm{r}=0.515$ dan $\mathrm{p}=0.000(\mathrm{p}<0.01)$.

Hal ini dapat dimaknai bahwa semakin tinggi dukungan sosial di tempat kerja maka semakin tinggi pula keterikatan kerja dan demikian pula sebaliknya, semakin rendah dukungan sosial di tempat kerja maka semakin rendah pula keterikatan kerja. Dengan demikian, hipotesis penelitian yang diajukan peneliti sebelumnya dapat diterima, yaitu ada hubungan positif antara dukungan sosial di tempat kerja dan keterikatan kerja.

Hasil penelitian ini sejalan dengan penelitian yang dilakukan oleh Man dan Hadi (2013), yang menyatakan bahwa dukungan sosial di organisasi memiliki hubungan dengan tingginya keterikatan kerja seseorang. Bakker (2011) pun menyebutkan dalam penelitiannya bahwa dukungan sosial merupakan pendorong dari meningkatnya keterikatan kerja yang masuk dalam sumber pekerjaan. Schaufeli, Bakker, dan Rhenens (2009) dalam penelitian longitudinalnya pada perusahaan telekomunikasi di Belanda menemukan bahwa ada perubahan terhadap keterikatan kerja selama 
satu tahun. Secara khusus, hasil penelitian menunjukkan bahwa peningkatan dukungan sosial, otonomi, kesempatan untuk belajar, dan umpan balik kinerja adalah prediktor positif dari keterikatan kerja dan dapat mengurangi intensitas absen dalam bekerja.

Dukungan sosial di tempat kerja dapat membuat individu merasakan kenyamanan ketika bekerja. Adanya dukungan sosial dapat meredam bentuk-bentuk stres kerja yang merupakan oposisi dari keterikatan kerja. Dukungan sosial dapat mengurangi beban atau permasalahan yang dihadapi seseorang sehingga dapat dikatakan bahwa dukungan sosial merupakan model dukungan yang dihasilkan dari interaksi pribadi yang melibatkan salah satu atau lebih aspek emosi, penilaian, informasi, dan instrumen sehingga dapat mereduksi beban yang diterima individu.

Xanthopoulou dkk. (2012) dalam penelitian mengatakan bahwa karyawan yang merasa antusias dan berenergi karena penilaian positif dari rekan kerjanya seperti mendapatkan dorongan pada efikasi diri dan sikap optimis. Hal ini membuktikan bahwa dukungan sosial yang tinggi dari rekan kerja dapat membuat individu memiliki kepercayaan diri dan merasa optimis dalam melakukan pekerjaannya. Studi ini pun mengemukakan interaksi rekan kerja baik atasan maupun bawahan dapat memicu emosi positif pada individu.

Individu yang memiliki keterikatan kerja yang baik akan memiliki kinerja yang lebih baik. Bakker dan Demerouti (2008) menyebutkan empat alasan yang menyebabkan individu yang memiliki keterikatan kerja memiliki kinerja lebih baik yaitu emosi positif, pengalaman kesehatan yang lebih baik, membuat sendiri sumber personal dan pekerjaan, dan mentransfer keterikatan dengan orang lain. Individu yang memiliki keterikatan kerja akan memiliki suasana hati yang positif serta sikap optimis dan hal ini akan dapat mempengaruhi individu lainnya yang berada di sekitarnya. Hal ini pun akan berdampak dalam tim apabila individu-individu di dalamnya memiliki keterikatan kerja yang baik dan akan membuat tim menjadi lebih berkinerja dengan baik.

Pada penelitian ini ditemukan bahwa tidak ada perbedaan keterikatan kerja antara individu yang bekerja pada perusahaan perbankan dan pelayanan air minum (PDAM). Hal ini menunjukkan tidak ada perbedaan keterikatan kerja antara perusahaan perbankan dan pelayanan air minum. Dua sektor perusahaan ini memiliki keterikatan kerja yang sama. Besar sumbangsih pengaruh dukungan sosial pada keterikatan kerja dalam penelitian ini sebesar $24.8 \%$. Hal ini bermakna bahwa dukungan sosial di tempat kerja memiliki pengaruh yang relatif kecil terhadap keterikatan kerja. Terdapat faktor-faktor selain dukungan sosial yang dapat berpengaruh pada keterikatan kerja individu.

Penelitian ini tentu memiliki keterbatasan. Adapun keterbatasan dalam penelitian ini adalah pemilihan variabel independen yang hanya berfokus pada satu variabel saja. Mengingat bahwa ada faktor lain yang mempengaruhi keterikatan kerja sehingga tidak sepenuhnya keterikatan kerja dipengaruhi oleh dukungan sosial di tempat kerja. Faktor tersebut adalah otonomi, kesempatan untuk belajar, dan umpan balik kinerja (Schaufeli, Bakker, \& Rhenens, 2009). Keterikatan kerja dalam penelitian ini berada pada konteks organisasi. Dukungan sosial yang diterima individu merupakan dukungan yang berasal dari rekan kerja. Sehingga tidak dapat menjadi acuan untuk individu-individu 
yang bekerja secara independen.

Berdasarkan hasil penelitian yang telah dilakukan, maka diperoleh kesimpulan bahwa ada hubungan positif antara dukungan sosial di tempat kerja dan keterikatan kerja. Artinya, semakin tinggi dukungan sosial di tempat maka semakin tinggi pula keterikatan kerja. Sebaliknya, semakin rendah dukungan sosial, maka semakin rendah juga keterikatan kerja. Mengingat bahwa dukungan sosial di tempat kerja hanya memberikan sumbangan sebanyak $24.8 \%$, maka dianjurkan pada peneliti selanjutnya melihat faktor-faktor lain yang dapat memberikan sumbangan yang besar pada keterikatan kerja. Keterikatan kerja pada penelitian ini juga tidak dapat digeneralisasikan pada individu-individu yang bekerja secara mandiri atau tidak pada organisasi. Diharapkan peneliti selanjutnya meneliti keterikatan kerja pada individu-individu tertentu yang tetap terikat pada pekerjaannya dalam kondisi tidak mendapatkan dukungan sosial dari lingkungannya.

\section{Daftar Pustaka}

Azwar, S. (2012). Penyusunan Skala Psikologi Edisi II. Yogyakarta: Pustaka Pelajar.

Bakker, A. B. (2011). An evidence-based model of work engagement. Current Directions in Psychological Science, 20(4), 265-269.

Bakker, A. B., Albrecht, S. L., \& Leiter, M. P. (2011). Key questions regarding work engagement. European Journal of Work and Organizational Psychology, 20(1), 4-28.

Bakker, A. B., \& Demerouti, E., (2008). Towards a model of work engagement. Career Development International.
13(3), 209-223.

Bakker, A. B., Schaufeli, W. B., Leiter, M. P., Taris, T. W. (2008). Work engagement: An emerging concept in occupational health psychology. Work \& Stress, 22(3), 187-200.

Brummelhuis, L. L., \& Bakker, A. B. (2012). Staying engaged during the week: The effect of off-job activities on next day work engagement. Journal of Occupational Health Psychology, 17(4), 445-455.

Cziksentmihalyi, M. (1990). The Psychology of Optimal Experience. New York: Harper \& Row publishers.

Fermin, J. (2014). 13 Disturbing Facts about Employee Engagement. Officevibe. Retrived from https://www.office vibe.com/blog/disturbing-employeeengagement-infographic.

Gorgievski, M. J., \& Bakker, A. B. (2010). Passion for work: Work engagement versus workaholism. In S. L. Albrecht (Eds.), Handbook of Employee Engagement (hal. 264-271).

Kahn, W. A. (1990). Psychological conditions of personal engagement and disengagement at work. Academy of Management Journal, 33, 692-724. Cheltenham: Edward Elgar Publishing.

Man, G. S., \& Hadi, C. (2013). Hubungan antara perceived organizational support dengan work engagement pada guru SMA swasta di Surabaya. Jurnal Psikologi Industri dan Organisasi, 2(2). 90-99.

Schaufeli. W. B. (2012). Work engagement: What do we know and where do we go? Romanian Journal of Applied 
Psychology, 14(1), 3-10.

Schaufeli, W. B., \& Bakker, A. B. (2003). UWES, Utrecht Work Engagement Scale. Utrecht: Occupational Health Psychology Unit Utrecht University.

Schaufeli, W. B., \& Bakker, A. B. (2004). Job demands, job resources and their relationship with burnout and engagement: A multisample study. Journal of Organizational Behavior, 25, 293-315.

Schaufeli, W. B., Bakker, A. B., \& Rhenens, W. V. (2009) How changes in job demands and resources predict burnout, work engagement, and sickness absenteeism. Journal of Organizational Behaviour, 30, 893-917.

Sinokki, M., (2011). Social Factor at Work and the Health of Employee. Tampere: Juvenes Prints.

Xanthopoulou, D., Bakker, A. B., Demerouti, E., \& Schaufeli, W. B., (2012). A diary study on the happy worker: How job resources relate to positive emotions and personal Resources. European Journal of Work and Organizational Psychology, 21(4), 489-517. 